\title{
When is a high fat diet not a high fat diet? Richard D Feinman*
}

\author{
Address: Department of Biochemistry, State University of New York Downstate Medical Center, Brooklyn, NY 11203 USA \\ Email: Richard D Feinman* - rfeinman@downstate.edu \\ * Corresponding author
}

Published: 17 October 2005

Nutrition \& Metabolism 2005, 2:27 doi:10.1 186/1743-7075-2-27
Received: 04 October 2005

Accepted: 17 October 2005

This article is available from: http://www.nutritionandmetabolism.com/content/2/1/27

(C) 2005 Feinman; licensee BioMed Central Ltd.

This is an Open Access article distributed under the terms of the Creative Commons Attribution License (http://creativecommons.org/licenses/by/2.0), which permits unrestricted use, distribution, and reproduction in any medium, provided the original work is properly cited.

The observation that a high fat/low carbohydrate $(\mathrm{CHO})$ diet has a beneficial effect on a mouse model of Alzheimer's disease (AD) published today is notable given previous results showing that high fat diets have a deleterious effect on AD. Van de Auwera, et al. [1] reported that mice fed a ketogenic diet $(<1 \%$ carbohydrate, $80 \%$ fat) were found to have a $25 \%$ decrease in the protein $A \beta 42 \mathrm{com}$ pared to mice fed a standard high-carbohydrate, low-fat chow diet. $A \beta 42$ is a particularly amyloidogenic mutant form of the amyloid precursor protein whose proteolytic product $\beta$-amyloid peptide is contained in the plaques and neurofibrillar tangles that are characteristic of $\mathrm{AD}$.

Any suggestion of an environmental or dietary attack on $\mathrm{AD}$ is welcome given the devastating effects of the disease. Beyond the potential application, however, Van de Auwera, et al.'s results have general implications for nutritional approaches in biochemistry and cell biology, and ultimately on disease processes. The physiologic effect of dietary fat can be significantly modulated by the presence of carbohydrate and the associated hormonal changes. The description "high fat diet" is thus an inadequate way to characterize a diet. One must also specify the level of carbohydrate.

The principle that dietary fat might play a relatively passive role in metabolism and that the disposition of fat is regulated by the hormonal state stimulated by carbohydrate is taught in elementary courses in biochemistry but remains an under-appreciated factor in many studies, possibly due to the emphasis on low-fat recommendations of nutritional agencies. Because of the requirement of brain cells for glucose (or ketones) for energy metabolism and, in particular, because of the known involvement of insu- lin in regulating secretase (proteolytic enzyme in $\beta$-amyloid production) (e.g. [2]), it is pertinent to inquire about the role of macronutrient composition in the diet in neuronal disorders. The role of energy metabolism in brain function has been discussed in a recent review and hypothesis by Mukherjee and Seyfried [3].

In explaining the importance of macronutrient composition to students we emphasize energy metabolism and gain or loss of body weight and we stress the need to get away from the principle that "you are what you eat," and replace it with the idea that "you are what you do with what you eat [4]." A common analogy, that fat is the bomb and carbohydrate is the fuse, or in its original description, powder keg and tinder box, may be too broad for appreciation of fine control of metabolism but is probably good enough to illustrate the principle here. Although there are many effects of dietary change, to a first order approximation, carbohydrate is the major stimulus for insulin secretion and as an anabolic hormone, leads to repression of lipolysis and glycogenolysis. Continued hyperinsulinemia, therefore, may predispose to a state where dietary fat is stored rather than oxidized. In addition, current thinking on insulin resistance emphasizes the role of free fatty acids and other fat metabolites (e.g. $[5,6])$. One theory of the etiology of insulin resistance is that insulin resistance in the adipocyte represents down regulation of response due to continued hyperinsulinemia. This causes increased lipolysis and excessive liberation of fatty acids which may have several effects in peripheral tissues. Thus, the regulation of the TAG-fatty acid axis may be more important than the dietary levels of fat itself. 
Table I: Similarity of starvation and carbohydrate restriction

\begin{tabular}{rcccc}
\hline Reference [I I] & FFA $(\mu \mathrm{mol} / \mathrm{l})$ & fat oxidation $(\mu \mathrm{mol} / \mathrm{kg} / \mathrm{min})$ & Glucose $(\mathrm{mg} / \mathrm{dl})$ & $\beta$-hydroxybutyrate $(\mathrm{mM})$ \\
\hline Fast 84 h & 0.92 & 1.94 & 68 & 2.56 \\
Fast + Lipid & 1.02 & 1.67 & 66 & 2.54 \\
\hline
\end{tabular}

Data from reference [II]. Procedure as described in the text.

\section{Similarity of starvation and carbohydrate restriction}

One of the areas bearing on the idea that disposition of fat is controlled by insulin is the observation made by several groups that the metabolic response to starvation resembles the response to carbohydrate restriction [7-11]. An important but, in our view, under-appreciated study is that of Klein \& Wolfe [11] who compared responses of subjects on an 84 hour fast to the same subjects on a similar fast in which lipids were infused at a level equal to resting energy requirements. Table 1 shows that the levels of fatty acid, rates of oxidation and levels of glucose and ketone bodies were similar in the two groups (Table 1). These rather dramatic results were summarized by the authors as demonstrating that "carbohydrate restriction, not the presence of a negative energy balance, is responsible for initiating the metabolic response to fasting." It might be said that this is the key experiment in understanding the interaction between fat and carbohydrate. Similarly, Bisschop, et al. [8] demonstrated a similarity between high carbohydrate, low fat diets (CHO:Lipid:Protein $=85: 0: 15)$ and control (44:41:15) diets in FFA rate of appearance and oxidation but significant differences with a low carbohydrate, high fat diet (CHO:Lipid:Protein = 2:83:15).

\section{High fat diets in obesity}

The interaction of fat and carbohydrate bear on the mechanism of weight loss strategies based on carbohydrate restriction. In considering the problem, it is important to recognize that percentages are misleading. There are really three degrees of freedom in design or analysis of a weight loss experiment: two of the three macronutrients and the total caloric intake. It is unlikely that the percentage rather than the absolute amount of macronutrients is the controlling variable and at least three published studies show that carbohydrate reduction is not necessarily accompanied by replacement with either fat or protein but rather caloric reduction due to the carbohydrate removed [1214]. Such diets are effectively high fat by percentages but lead to substantial weight loss.

To understand the relative impact of carbohydrate and fat, one has to consider experiments in which one macronutrient is replaced by another. Several studies in the litera- ture have demonstrated that in isocaloric comparisons, the replacement of dietary carbohydrate with fat leads to greater weight loss [15-19], that is, the absence of the fuse prevents an explosive effect of dietary fat on body mass. The limitations of the fat bomb per se are reviewed by Willett and Leibel [20].

\section{Cardiovascular disease}

Many of the objections over the years of controlling the effect of dietary fat by replacing dietary carbohydrate has centered on the "obvious" danger that high fat diets present to plasma lipids and coronary risk. The subject is more complicated than obesity in that the mechanistic role of insulin is less well understood and the type of fat becomes much more important. Moreover, the relative importance of different risk factors LDL vs. triglycerides and HDL may be a matter of clinical judgment. However, what we know from epidemiology is that, whereas replacing unsaturated fat (UF) with saturated fat is deleterious to CVD outcome, replacing UF with carbohydrate is worse [21]. Similar effects are seen on the effect of dietary replacement on total cholesterol/HDL [22]. The generally beneficial effects of carbohydrate reduction on lipid profile has been reviewed by Volek [23].

\section{Diabetes}

Control of lipid metabolism by insulin is of greatest importance in diabetes where insulin insufficiency or resistance is the key variable. The subject is a matter of current controversy since official organizations counsel against high-fat diets: the American Diabetes Association position statement, for example, presents an expert consensus for $60-70 \%$ of energy intake as carbohydrates for diabetics. Such high intake of the major insulin secretagogue as a therapeutic strategy remains counter-intuitive and may not even be known to or implemented by many practicing physicians and the idea has recently been strongly criticized $[24,25]$.

A widely quoted example of experiments bearing on this question is the study of Garg, et al. [26,27]. In a fourcenter randomized crossover trial, carbohydrate was replaced with monounsaturated fats (CHO: $55 \% \rightarrow 40$; total fat: $30 \% \rightarrow 45$ ) or, conversely, MUF was replaced with $\mathrm{CHO}$. It was found that replacement of MUF with 


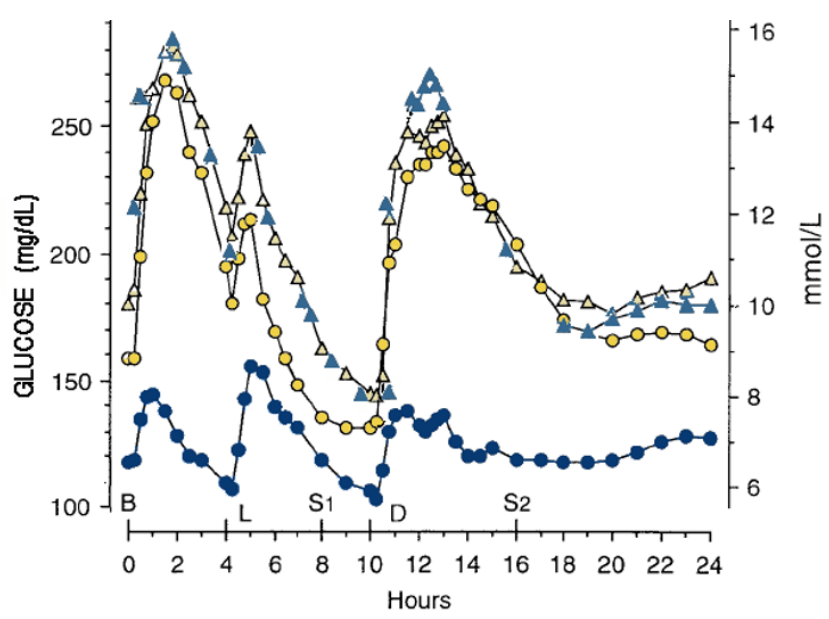

Figure I

Effect of diet on glucose. Mean plasma glucose concentration before (triangles) and after 5 weeks on control diet (yellow circles: (CHO:fat:protein = 55:30: 15)) or 5 weeks on the higher fat diet (blue circles: (20:50:30)). Meals are Breakfast (B), lunch (L) and dinner(D) plus 2 snacks (SI, S2). Data from reference [28].

carbohydrate "caused persistent deterioration of glycemic control and accentuation of hyperinsulinemia, as well as increased plasma triglyceride and very-low-density lipoprotein cholesterol levels, which may not be desirable [26]," that is, the high fat arm was beneficial, again, suggesting that what happened to the fat was more important than its concentration in the diet.

To determine the relative importance of fat and carbohydrate and protein, Gannon and coworkers have measured the effect of replacement of carbohydrate with protein and fat in patients with type 2 diabetes [28]. Figure 1 shows the effects on glycemic control of the replacement of carbohydrate with protein and fat. Again, the 50\% fat diet provides better glycemic control although, in this case, the relative contributions of carbohydrate reduction and increase in protein is unknown.

\section{Conclusion}

The long range implication of Van de Auwera's study for AD remains to be seen but the general lesson is that in dietary recommendations or in testing animal models a diet should not be characterized as high fat without also specifying the level of carbohydrate.

\section{References}

I. Van der Auwera I, Wera S, Van Leuven F, Henderson ST: A ketogenic diet reduces amyloid beta 40 and 42 in a mouse model of Alzheimer's disease. Nutr Metab (Lond) 2005, 2:28.

2. Solano DC, Sironi M, Bonfini C, Solerte SB, Govoni S, Racchi M: Insulin regulates soluble amyloid precursor protein release via phosphatidyl inositol 3 kinase-dependent pathway. Faseb J 2000, 14(7): 1015-1022.

3. Mukherjee P, Seyfried TN: Metabolic Targeting of Brain Cancer. Nutr Metab (Lond) 2005, 2:30.

4. Feinman RD, Makowske M: Metabolic Syndrome and Low-Carbohydrate Ketogenic Diets in the Medical School Biochemistry Curriculum. Metabolic Syndrome and Related Disorders 2003, I:189-198.

5. Boden G, Laakso M: Lipids and glucose in type 2 diabetes: what is the cause and effect? Diabetes Care 2004, 27(9):2253-2259.

6. Kim JK, Fillmore JJ, Sunshine MJ, Albrecht B, Higashimori T, Kim DW, Liu ZX, Soos TJ, Cline GW, O'Brien WR, Littman DR, Shulman GI: PKC-theta knockout mice are protected from fat-induced insulin resistance. J Clin Invest 2004, I I 4(6):823-827.

7. Azar GJ, Bloom WL: Similarities Of Carbohydrate Deficiency And Fasting. II. Ketones, Nonesterified Fatty Acids And Nitrogen Excretion. Arch Intern Med 1963, I I 2:338-343.

8. Bisschop PH, Ackermans MT, Endert E, Ruiter AF, Meijer AJ, Kuipers F, Sauerwein HP, Romijn JA: The effect of carbohydrate and fat variation in euenergetic diets on postabsorptive free fatty acid release. Br J Nutr 2002, 87(6):555-559.

9. Bloom WL, Azar GJ: Similarities Of Carbohydrate Deficiency And Fasting. I. Weight Loss, Electrolyte Excretion, And Fatigue. Arch Intern Med 1963, I I 2:333-337.

10. Fery F, Bourdoux P, Christophe J, Balasse EO: Hormonal and metabolic changes induced by an isocaloric isoproteinic ketogenic diet in healthy subjects. Diabetes Metab 1982, 8(4):299-305.

II. Klein S, Wolfe RR: Carbohydrate restriction regulates the adaptive response to fasting. Am J Physiol 1992, 262(5 Pt I):E63I-6.

12. Boden G, Sargrad K, Homko C, Mozzoli M, Stein TP: Effect of a lowcarbohydrate diet on appetite, blood glucose levels, and insulin resistance in obese patients with type 2 diabetes. Ann Intern Med 2005, I 42(6):403-4II.

13. Larosa JC, Fry AG, Muesing R, Rosing DR: Effects of high-protein, low-carbohydrate dieting on plasma lipoproteins and body weight. J Am Diet Assoc 1980, 77(3):264-270.

14. Miller BV, Bertino J, Reed TG, Burrington C, Davidson LK, Green A, Gartung A, Nafziger A: An Evaluation of the Atkins' Diet. Metabolic Syndrome and Related Disorders 2003, I:299-309.

15. Baba NH, Sawaya S, Torbay N, Habbal Z, Azar S, Hashim SA: High protein vs high carbohydrate hypoenergetic diet for the treatment of obese hyperinsulinemic subjects. Int J Obes Relat Metab Disord 1999, 23(I I): 1202-1206.

16. Golay A, Eigenheer C, Morel Y, Kujawski P, Lehmann T, de Tonnac $\mathrm{N}$ : Weight-loss with low or high carbohydrate diet? Int J Obes Relat Metab Disord 1996, 20(12): 1067-1072.

17. Rabast U, Kasper H, Schonborn J: Comparative studies in obese subjects fed carbohydrate-restricted and high carbohydrate I,000-calorie formula diets. Nutr Metab 1978, 22(5):269-277.

18. Sharman MJ, Kraemer WJ, Love DM, Avery NG, Gomez AL, Scheett TP, Volek JS: A ketogenic diet favorably affects serum biomarkers for cardiovascular disease in normal-weight men. J Nutr 2002, 132(7): 1879-1885.

19. Volek JS, Sharman MJ, Gomez AL, Judelson DA, Rubin MR, Watson G, Sokmen B, Silvestre R, French DN, Kraemer WJ: Comparison of energy-restricted very low-carbohydrate and low-fat diets on weight loss and body composition in overweight men and women. Nutr Metab (Lond) 2004, I (I): 13.

20. Willett WC, Leibel RL: Dietary fat is not a major determinant of body fat. Am J Med 2002, I I 3 Suppl 9B:47S-59S.

21. Hu FB, Manson JE, Willett WC: Types of dietary fat and risk of coronary heart disease: a critical review. J Am Coll Nutr 200I, 20(I):5-19.

22. Mensink RP, Zock PL, Kester AD, Katan MB: Effects of dietary fatty acids and carbohydrates on the ratio of serum total to HDL cholesterol and on serum lipids and apolipoproteins: a meta-analysis of 60 controlled trials. Am J Clin Nutr 2003, 77(5): I I 46-I I 55.

23. Volek JS, Sharman MJ, Forsythe CE: Modification of lipoproteins by very low-carbohydrate diets. J Nutr 2005, I 35(6): I 339-1342.

24. Arora SK, McFarlane SI: The case for low carbohydrate diets in diabetes management. Nutr Metab (Lond) 2005, 2:16. 
25. McFarlane SI: Dietary recommendations for people with diabetes: Time to reduce the carbohydrate loads. Endocrine Today 2005, 3(9):4-5.

26. Garg A, Bantle JP, Henry RR, Coulston AM, Griver KA, Raatz SK Brinkley L, Chen YD, Grundy SM, Huet BA, et al.: Effects of varying carbohydrate content of diet in patients with non-insulindependent diabetes mellitus. Jama 1994, 27 ( ( 8 ): | 42 I- I 428.

27. Garg A, Grundy SM, Koffler M: Effect of high carbohydrate intake on hyperglycemia, islet function, and plasma lipoproteins in NIDDM. Diabetes Care 1992, I 5(I I): I572-I580.

28. Gannon MC, Nuttall FQ: Effect of a high-protein, low-carbohydrate diet on blood glucose control in people with type 2 diabetes. Diabetes 2004, 53(9):2375-2382.

Publish with Bio Med Central and every scientist can read your work free of charge

"BioMed Central will be the most significant development for disseminating the results of biomedical research in our lifetime. "

Sir Paul Nurse, Cancer Research UK

Your research papers will be:

- available free of charge to the entire biomedical community

- peer reviewed and published immediately upon acceptance

- cited in PubMed and archived on PubMed Central

- yours - you keep the copyright

Submit your manuscript here:

http://www.biomedcentral.com/info/publishing_adv.asp 